Available online on 15.11.2020 at http://jddtonline.info
Open Access to Pharmaceutical and Medical Research
unrestricted non-commercial use, provided the original work is properly cited

Open $\odot$ Access

Research Article

\title{
Research of the Causes and Risk Factors of Autism in the Western Region of
} Algeria

\author{
Mehida Hayet ${ }^{2}$, Meziani Samira ${ }^{2}$, Mehida Ouahiba ${ }^{3}$, Zemri Khalida ${ }^{4}$, Bekhaled Imene ${ }^{2}$, Bendahmane \\ Malika 5 \\ 1 Laboratory of Molecular Microbiology, Proteomics and Health. Department of biology. Faculty of Natural and Life Sciences University Djilali \\ Liabes, Sidi-Bel-Abbes, Algeria \\ 2 Biotoxicology Laboratory. Department of Biology Faculty of Natural and Life Sciences, Djillali Liabes University of Sidibel Abbes, Algeria \\ 3 Department of sociology, Faculty of human sciences, Djillali Liabes University of Sidi bel Abbes,Algeria \\ 4 Department of biology. Faculty of Natural and Life Sciences University Djilali Liabes, Sidi-Bel-Abbes, Algeria \\ 5 Environment and health research laboratory, faculty of medicine Djillali Liabes University of Sidi bel Abbes, Algeria
}

\section{ABSTRACT}

Introduction Autism is a neurodevelopmental disorder that manifests before 3 years old and affects many areas, communication, social interactions and behaviors. In Algeria, there has not yet been a regional or national epidemiological investigation concerning autism spectrum disorders.

Materials and methods: Our study was carried about 100 patients ( autistic children) in the western region of Algeria, in order to determine the differents risk factors involved in the onset of autism syndrome.

Results and discussion: The obtained results indicate a male predominance with a sex ratio of $4: 1$ and the degree of reached is average in $44 \%$ of patients. $42 \%$ of the patients are youngsters. Parents' worry about their children begins between 24 and 36 months. The parents' advanced age at conception, stress, presence of certain pathologies and drug intake by mothers, as well as fetal distress at birth and children's exposure to screens were the main risk factors. Repetitive movements, lack of social communication, language delay, and lack of visual fixation were the main clinical symptomatology.

Conclusion: This study allowed us to detect the main factors associated with the onset of autism. However, the results obtained cannot be generalized to the entire population.

Keywords: Autism, autism spectrum disorder, risk factors, clinical symptoms, western region of Algeria.

Article Info: Received 08 Sep 2020; $\quad$ Review Completed 21 Oct 2020; $\quad$ Accepted 29 Oct 2020; $\quad$ Available online 15 Nov 2020

口ificis:

Mehida H, Meziani S, Mehida O, Zemri K, Bekhaled I, Bendahmane M, Research of the Causes and Risk Factors of Autism in the Western Region of Algeria, Journal of Drug Delivery and Therapeutics. 2020; 10(6):91-98

http://dx.doi.org/10.22270/jddt.v10i6.4563

*Address for Correspondence:

Mehida Hayet, Laboratory of Molecular Microbiology, Proteomics and Health. Department of biology. Faculty of Natural and Life Sciences University Djilali Liabes, Sidi-Bel-Abbes, Algeria

\section{INTRODUCTION}

Autism is a neurodevelopmental disorder, first described medically by Kanner in 1943. The WHO International Classification of Diseases (ICD-10) describes autism as a pervasive developmental disorder, defined by a qualitative alteration of communication, socialization and the presence of stereotypical behaviors and restricted interests. The disorders must have appeared early in early childhood and pervade the person's entire functioning ${ }^{1}$

Two reference classifications, (ICD -10 and DSM-5, also highlight the heterogeneity of autism, and are the subject of regular updates reflecting the advances made in knowledge of autism, are internationally recognized by the scientific community. There is also a French Classification of Mental Disorders in Children and Adolescents (CMDCA) ${ }^{2}$.

Autism affects three to four times as many boys as girls and affects 1 in 160 children worldwide according to the latest WHO estimates ${ }^{3}$. In Algeria, studies have found that the number of cases of autism is between 400,000 and 500,000 cases ${ }^{4}$. The increased frequency of autism in recent decades is a major problem of public health. As a result, several studies have been carried out to identify the neurological, genetic, parental and environmental factors involved in the complex and multifactorial aetiology of this disease ${ }^{5}$. To date, there is no reliable biological or imaging marker available to diagnose autism. The diagnosis is therefore made exclusively by clinical evaluation of subjects ${ }^{6}$. The main objective of our study is to determine the risk factors and causes involved in the onset of autism, namely genetic, socioeconomic, and medical factors in young children living in the western region of Algeria (Sidi Bel Abbes, Oran and Tlemcen). 


\section{MATERIAL AND METHODS}

Our study has several objectives, the main one is to look for the causes and risk factors involved in the onset of autism, namely genetic, socio-economic factors, maternal health and medical history in young children residing in the Algerian West region Sidi Bel Abbes, Oran and Tlemcen, generate hypotheses about the cross-cause (s) responsible for this disorder

\section{1 Study framework:}

The study was carried out for four months (March-June 2019). The informations collected on the patients was gathered from a questionnaire, filled in by the parents of autistic children residing in the western region of Algeria. Our study was carried out in three localisations:

In sidi Bel Abbes city, the work was carried out in the child psychiatry department, private schools and a private speech therapist, in Oran city it was with a private speech therapist and finally the city of Tlemcen the work was realised in a private school.

\section{2 Study population:}

The study involved a sample of one hundred (100) autistic patients. The approach adopted for this study took into consideration several parameters in order to determine the factors having an influence on the appearance and / or evolution of autistic disorders.

Among the factors taken into account, we cite: age and sex of patients, order of birth, state of health of the child at birth and other associated pathologies, lifestyle, age of parents, consanguineous marriage, the mother's medical history, the mother's exposure to toxic substances, type of childbirth, type of breastfeeding, family history of autism, diagnosis and finally therapeutic and social care

\section{II.3. Data analysis :}

The data collected was computerized and processed with IBM SPSS software (version 22). Chi-square test analysis is performed for significance check ( $\mathrm{p}<0.05)$, followed by frequency analysis to calculate the percentage

\section{RESULTS AND DISCUSSIONS}

\section{III.1 Breakdown by Age}

From figure 1, we can deduce that patients aged 6 years are the most affected at $48 \%$ with extremes of 4 years and 11 years and an average age of 6.10 .

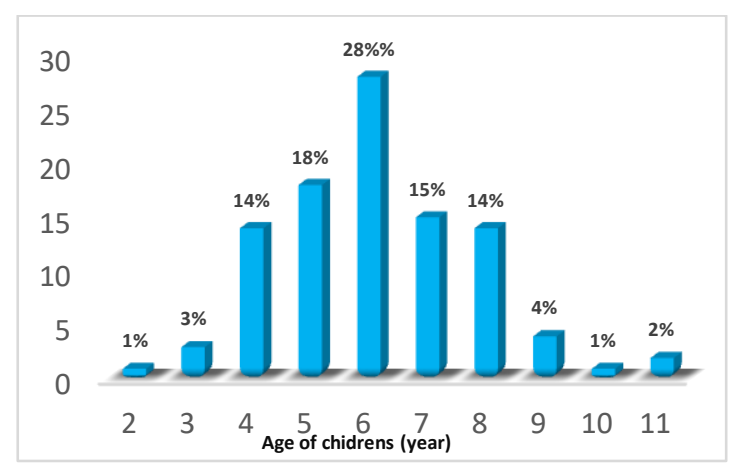

Figure 1 : Breakdown by Age

\section{III.2 Breakdown by gender}

Our results show that among the 100 autistic children, 79 are boys and 21 are girls with a male predominance and a sex ratio of $4: 1$ (fig 2).

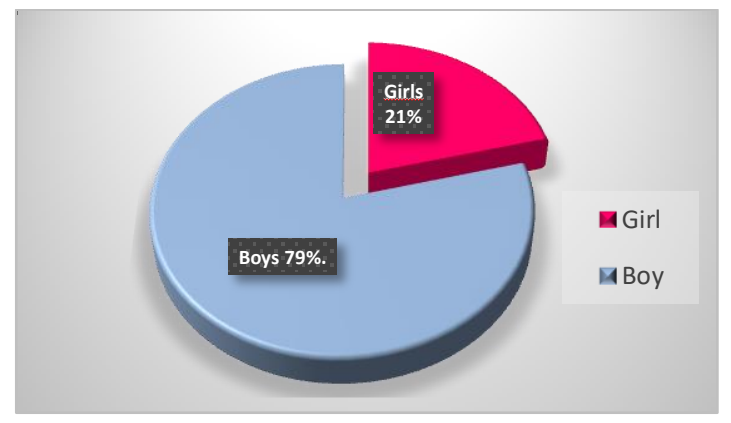

Figure 2 : Breakdown by gender

\section{III.3 Rank in siblings}

Our result (figure 4) reveals that the large number of patients affected by ASD are binjamin at $42 \%$ followed by Elder children with percentage of $27 \%$, as well as alone child and cadets with a rate of $15 \%$.

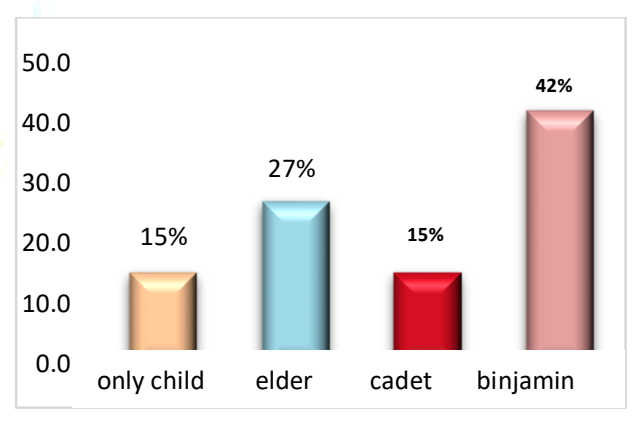

Figure 3 : Rank in siblings

\section{III.4 Distribution by degree of autism}

The histogram below shows that the most found degree of autism is the average degree with a percentage of $44 \%$. For the others we obtained a rate of $24 \%$ for mild autism and $12 \%$ for severe autism (fig 4).

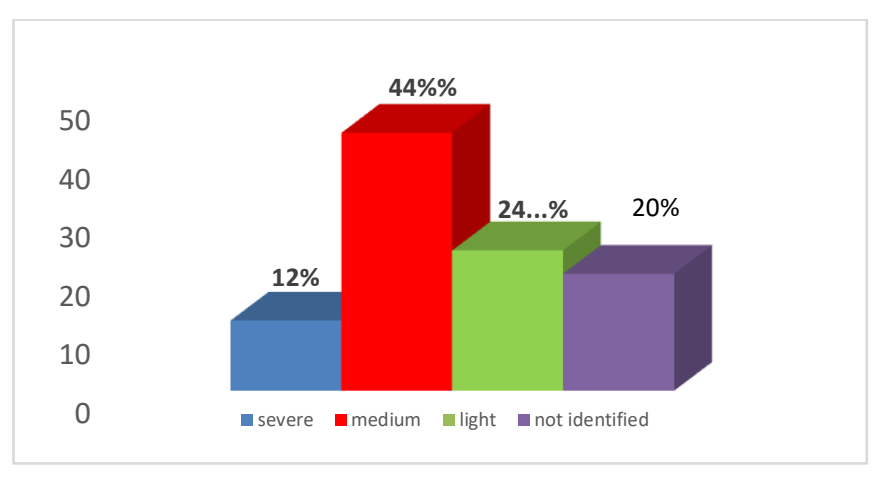

Figure 4 : degree of autism

\section{5 symptoms of autism}

The table below shows that the majority of the symptoms are present in our patients with a significant percentage. 
Table 1 : symptoms of autism

\begin{tabular}{|l|l|l|}
\hline Symptoms & Yes $\%$ & No $\%$ \\
\hline Repetitive movements (stereotypy) & 83 & 16 \\
\hline Withdrawal or lack of social communication & 88 & 12 \\
\hline Absence or delay of language & 80 & 20 \\
\hline Absence or reduction of the sensory aspect & 58 & 42 \\
\hline Absence or lack of pointing & 78 & 22 \\
\hline Absence or lack of demand & 86 & 14 \\
\hline Absence or lack of visual fixing & 83 & 17 \\
\hline Angry outbursts and aggressive gestures directed against oneself and others & 46 & 53 \\
\hline inability to play symbolic games & 62 & 37 \\
\hline loss of words or sentences already acquired after vaccination & 14 & 86 \\
\hline
\end{tabular}

\section{III .6 Child Health status at birth}

In our population, $29 \%$ of the children suffered fetal distress, $44 \%$ had low birth weight and $11 \%$ had neonatal jaundice, in the end $4 \%$ of the cases were premature.

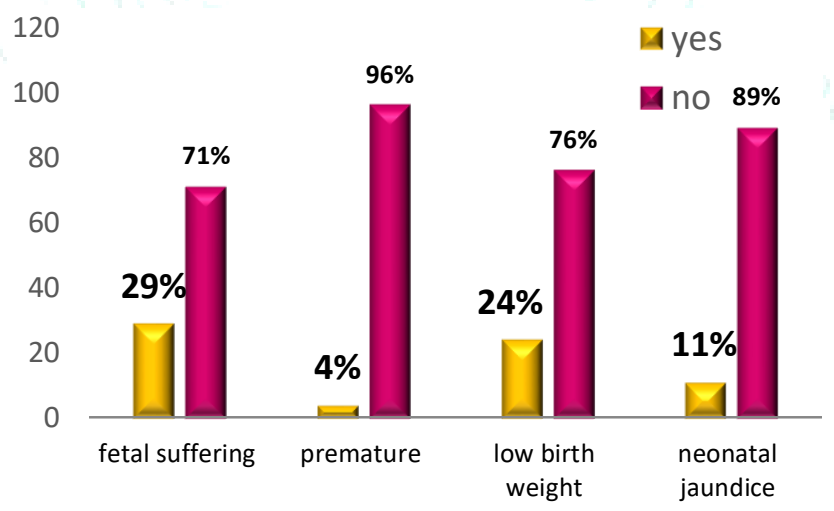

Figure 5 : child Health status at birth

\section{III .7 Physical and psychological development of the autistic child}

Histogram below represents the state of the child in the phase of normal development, it has been observed that a large number of patients had a delay in psycho-affective (83\%), psychomotor (65\%) and postural (52) development as well as a delay in weight (23\%) and statural (4\%) growth.

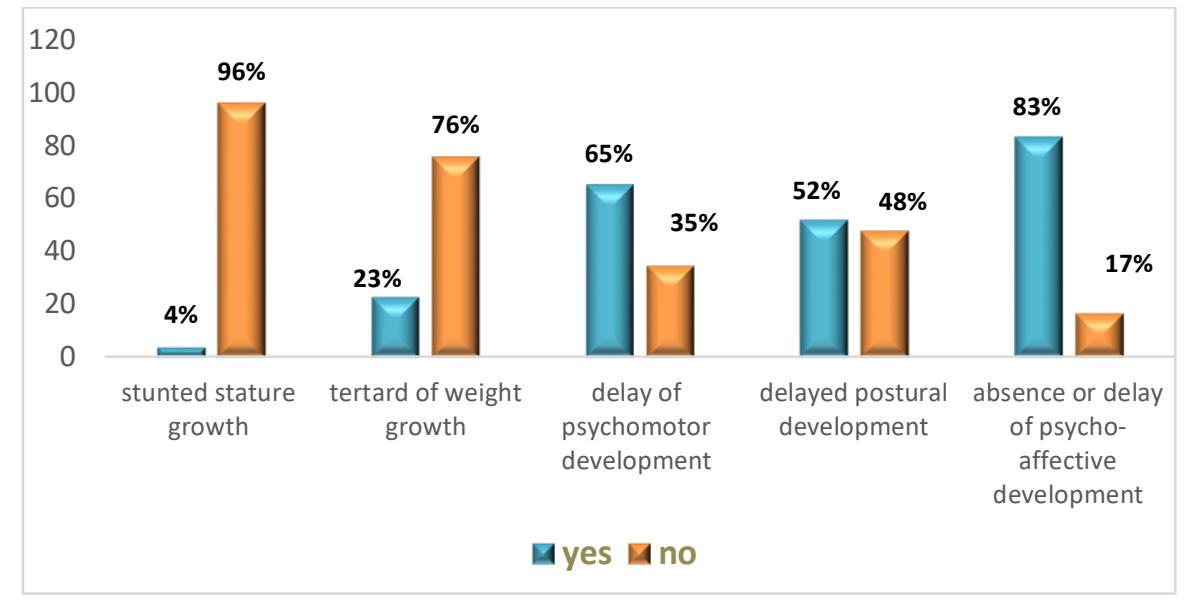

Figure 6 : Physical and psychological development of the autistic child 


\section{III .8 Early accidents of autistic children}

In our population a large number of $74 \%$ have not had accidents during early childhood, as well as $15 \%$ have had falls, $7 \%$ have had traumas and $4 \%$ have had psychic shocks.

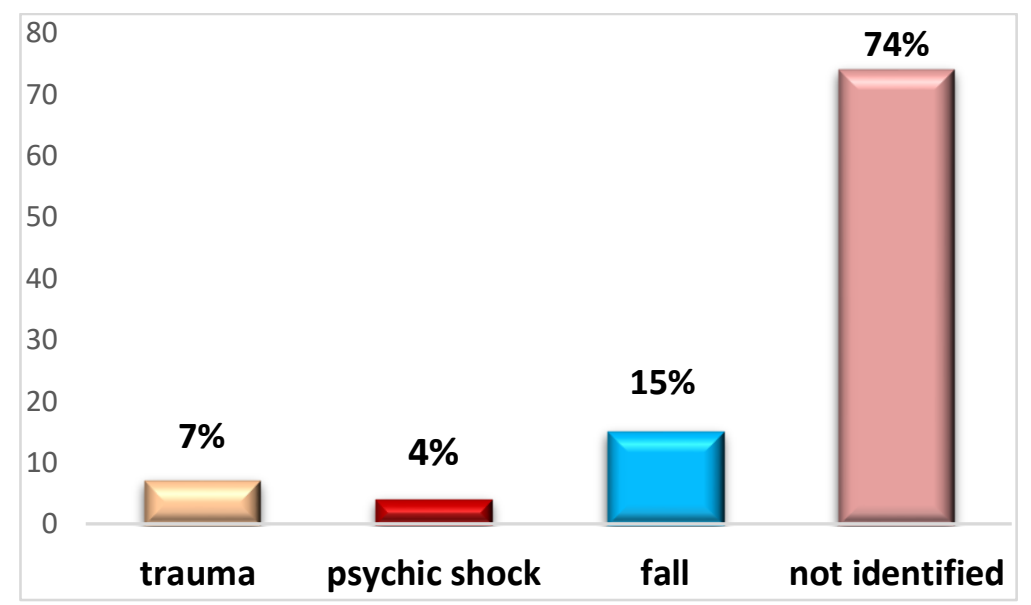

Figure 7 : Early accidents of autistic children

\section{III.9 Overexposure to the screens and autistic syndrom}

$85 \%$ of our patients were exposed to screens while $32 \%$ were exposed between 4 to 8 hours, $27 \%$ were in front of screens for less than 4 hours and $26 \%$ for more than 8 hours, in the end, $15 \%$ have not been identified.

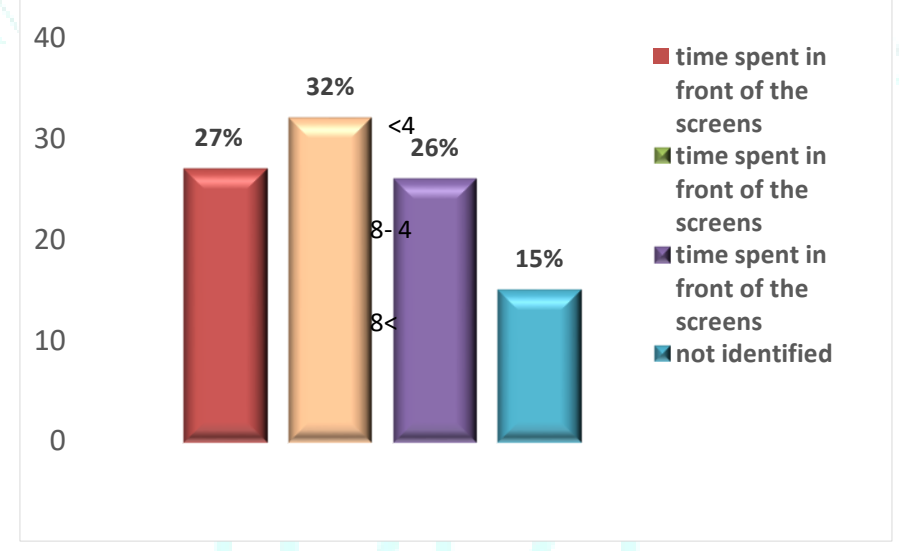

Figure 8 : Overexposure to the screens and autistic syndrom

\section{III .10 parents' first concerns}

The results below indicate that about $51 \%$ of parents note that their children's attitudes and behaviours are strange at ages between 44 and 33 months. It is at this point that parents begin to understand the seriousness of the problem.

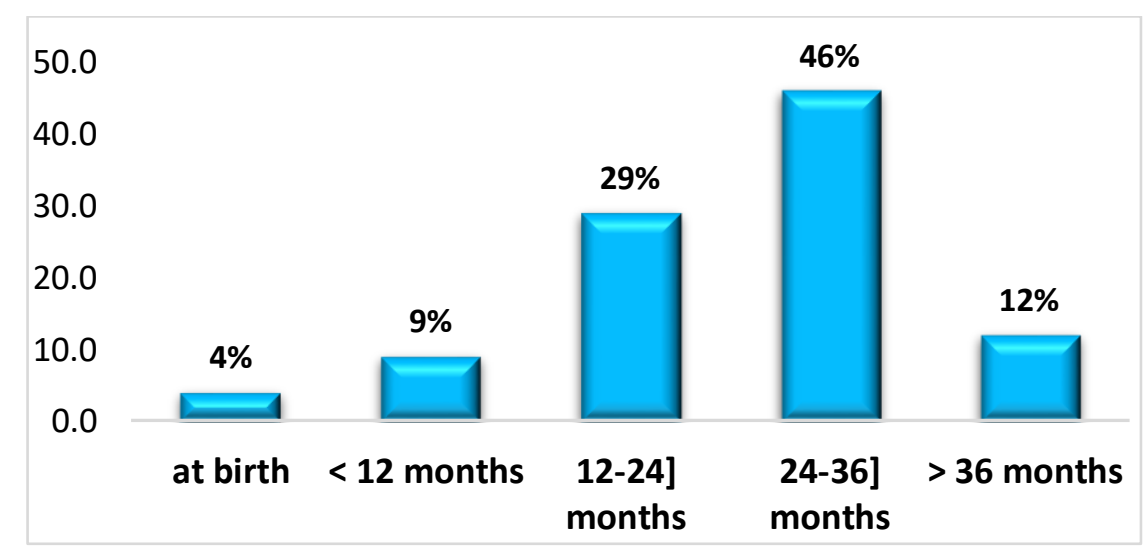

Figure 9: parents' first concerns 


\section{11 parental Age at birth of their children}

The results obtained for the parental age at the birth of their children are shown in the table below; however, the average age of fathers was 36.44, with extremes of 43 and 78, and the average age of mothers was 30.86, with extremes of 19 and 40 .

Table 2: parental age at birth of their children

\begin{tabular}{|l|l|l|l|}
\hline & The average & Standard deviation & Extreme age \\
\hline father & 36.44 & 7.260 & $23-78$ \\
\hline mother & 30.86 & 4.934 & $19-40$ \\
\hline
\end{tabular}

\section{12 Maternal Stress}

Stress is a complex term that encompasses a large number of reactions, but mothers in general may not be aware that stress during pregnancy is also a risk factor that can have a significant impact on the developing fetus. including the health, development and function of the immune system. Figure 10 shows that $57 \%$ of mothers of autistic children suffer from a stress disorder

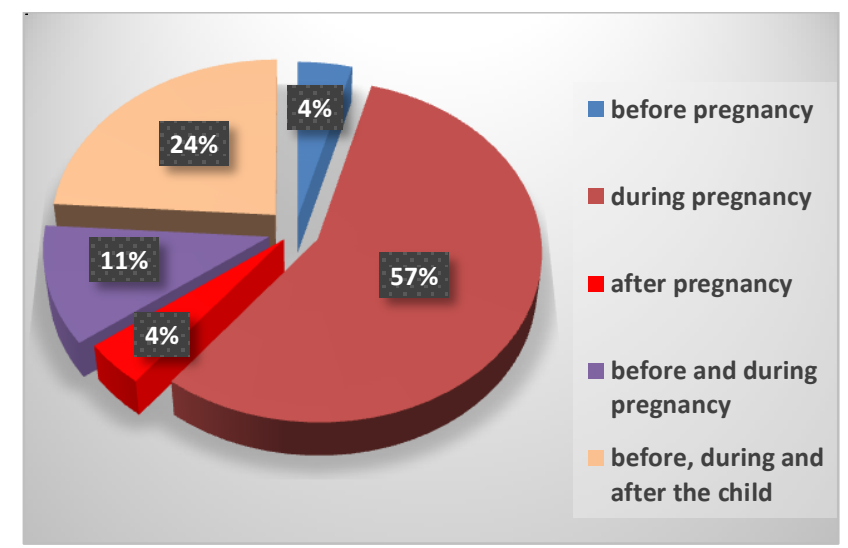

Figure 10 : Maternal Stress

III.13 Relationship between Maternal Stress and the degree of autism

We can see on the histogram below, that there is a significant correlation $(\mathrm{P}=0.011)$ between the degree of autism and the stress of the mother, a large number of children have an average degree of autism ( $43 \%$ ), followed by a mild degree with a percentage of $19 \%$ and $7 \%$ a severe degree.

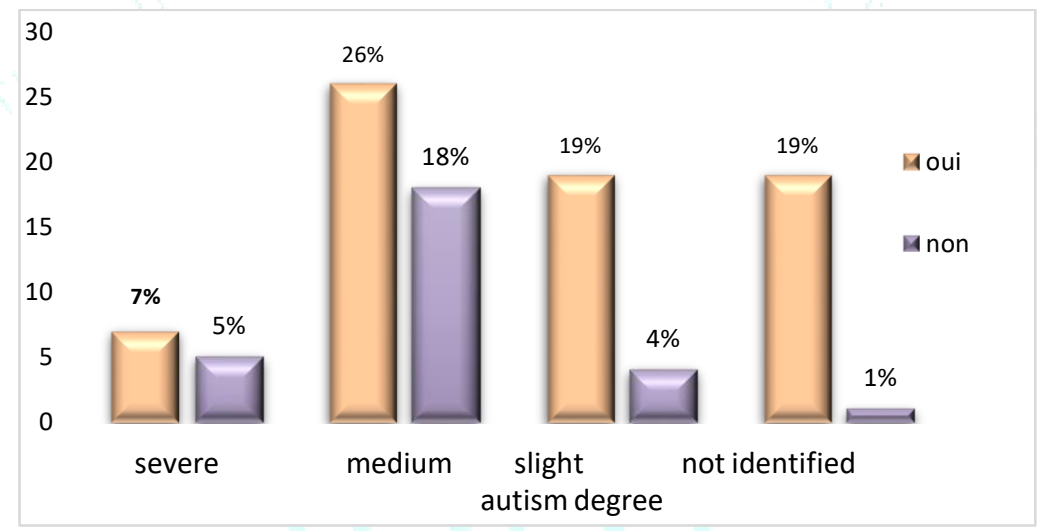

Figure 11 : Relationship between Maternal Stress and the degree of autism

\section{14 Mother's pathologies associated with autism}

Only $30 \%$ of mothers presented illnesses, 6\% had anemia followed by a percentage of $5 \%$ for mothers who presented infections during pregnancy and hypertension during pregnancy, thus $3 \%$ with thyroid pathology, $2 \%$ for type 1 and type 2 diabetes and a percentage of $1 \%$ of mothers had asthma and also $1 \%$ for mothers who presented a combination of two diseases such as anemia and fever, asthma and pregnancy-induced hypertension, gestational diabetes and infection.

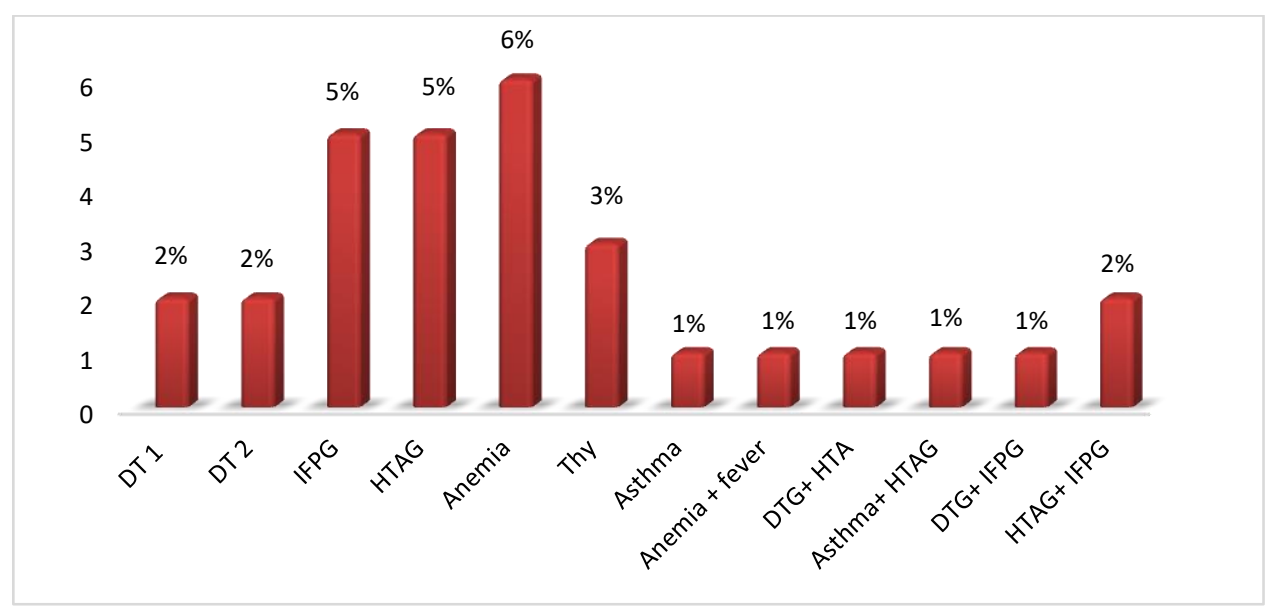

Figure 12 : Mother's pathologies associated with autism 


\section{15 Care of autistic childrens}

Our patients had multiple care, 34\% received psychological, speech therapy and medication, $26 \%$ were followed up psychologically and speech therapy, $15 \%$ were followed by the speech therapist alone, $12 \%$ received psychological care and $9 \%$ had received medication.

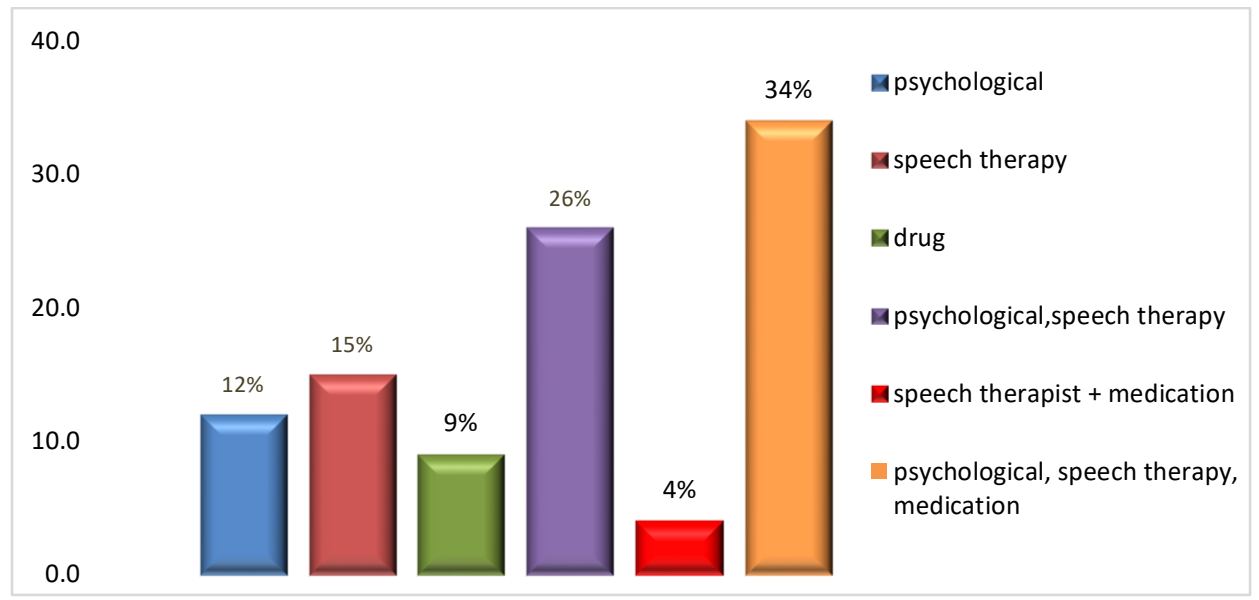

Figure 13 : Care of autistic childrens

\section{DISCUSSION}

According to the UN, Autism manifests itself in the first three years of life ${ }^{7}$. our results have shown that children aged 6 are the most affected This difference can be explained by the late management of the autistic child, that is to say that parents worries in general begin with the age of schooling.

Concerning distribution by gender our results are similar to ${ }^{8}$ and ${ }^{9}$. This imbalance between boy and girl can be explained by several factors:

Many genes located on the $\mathrm{X}$ chromosome have been used in autism. It could explain that girls would be protected against ASD compared to boys ${ }^{10,11}$. The study conducted by ${ }^{12}$ report the existence of a female protective effect against the development of ASD, which would give girls a higher tolerance threshold than boys with regard to the expression of the pathology ${ }^{13}$.

The role of sex hormones such as testosterone, which can increase the reduction in men to develop ASDs compared to women, has been mentioned ${ }^{14}$.

Our results do not agree with the study of ${ }^{15,16}$ which estimates that the firstborns were most likely to be affected by autism. Rather, other studies ${ }^{17}$ discovered that the youngest children are the most affected by autism.

Our results do not agree with the study by ${ }^{15,16}$ who estimate that firstborn children were the most likely to be affected by autism. Rather, other studies ${ }^{17}$ who have found younger children are the most affected by autism.

Autism does not manifest with the same frequency and intensity in all patients. Each person has their own particularities. The nature and intensity of the disorders vary from one person to another and also vary over time in the same person, and may also change depending the support offered. Thanks to good early and adapted educational care, an autist child can progress quickly and have every chance of integrating into society ${ }^{18}$.

Autism spectrum disorders are currently characterized by significant impairment in communication and social interaction, stereotyped and repetitive behaviours, and restricted interests ${ }^{19}$. In 2005, the neuro-pediatrician Cuiss and his collaborators 20 found that fetal suffering at the time of childbirth and prematurity were found in $40 \%$ of cases of pervasive developmental disorders a study conducted by ${ }^{21}$ indicates that low birth weight is a risk factor for ASD.

A survey carried out by ${ }^{22}$ showed that people born between the 28 th and 30th week of pregnancy had a 7.3 times higher risk of developing ASD than controls born at term. Another study by ${ }^{23}$ found that $9 \%$ of children with autism had neonatal jaundice, compared to $3 \%$ of children without autism. The authors explain that prolonged exposure to high levels of bilirubin can lead to developmental problems that can persist for the rest of a child's life.

There is No study speaks of a relationship between accidents in early childhood and autism. This result remains a hypothesis and may be a new sign in the world of autism.

Children with an Autism Spectrum Disorder are particularly vulnerable to various effects of screen time on the brain The Frampton Gwynett and his colleagues ${ }^{24}$ confirms our findings and indicates that screen exposure time is a risk factor for ASD 25 .

Regarding parents first concerns our results indicated that parents express their concern at all ages of their childrens and are much more significant between 44 and 33 months of age; however, other work $26,27,28$, show that parents generally begin to suspect developmental problems in their children between 12 and 24 months of age.

There is a significant association between the age of the child's parents at birth and the subsequent risk of developing an Autism Spectrum Disorder (ASD), Our results are consistent with $29,30,31$ who showed that the increase in ASD was not only limited to advanced parental age, but also to the age difference between them. These same results detected a significant influence of parental age on the risk of autism.

Other Studies 32,33 . confirm our findings, however, there is a strong link between high stress during pregnancy and the birth of an autistic child because it has a real impact on the pregnant woman and her fetus ${ }^{34}$.

Maternal disease may be a risk factor for ASD ${ }^{35}$ iron is essential for early brain development, however our results confirm the relationship between neonatal or maternal anemia, thyroid hormone levels, preeclampsia and ASD

According to the HAH, the objective of the care of autistic persons is to improve both their quality of life and that of their families. To do this, psychosocial approaches are implemented from childhood. Pharmacotherapy will only intervene in a second stage, only if psychosocial interventions have given an insufficient response in terms of behavioural improvement ${ }^{36}$. 


\section{CONCLUSION}

Autism is a neurodevelopmental disorder that manifests itself before the age of 3 and affects several areas. The increase in the number of cases of autism in recent decades constitutes a real public health and sociological problem.

The objective of our study was to investigate the causes and risk factors involved in the onset of autism, namely genetic, socio-economic factors, maternal health and medical history in young children.

The analytical study of our population reveals that out of 100 patients with autism, 79 are male and 21 are female, a predominantly male prevalence with a sex ratio of $4: 1$.

We observed that the average degree of autistic severity predominates. Moreover, the children most affected by this disorder are the youngest with a rate of $44 \%$, our results showed that parents' concern about their children begins at an age between 24 and 36 months.

We also found that the parents' advanced age at conception, stress, the presence of certain pathologies and the taking of medication by mothers, as well as fetal suffering at birth and the children's exposure to screens were the main risk factors. Nevertheless, the difficulties encountered during data collection do not allow us to have reliable results and to be able to draw conclusions.

The management of autistic syndrome is a child psychiatry issue, the neuropaediatric contribution is very complementary in the diagnostic process, a biological check-up is very necessary in order to search for an organic disorder at the origin of autism.

\section{In perspective, it is very interesting to:}

Mention the Apgar score in health records and establish a reliable diagnosis in order to benefit from early treatment to ensure good follow-up and a better quality of life for these children.

Create more parents' associations for a better awareness.

To train specialized health personnel and to create a permanent contact between these professionals and the parents in order to ensure a good continuity of work with these children.

Introduce new approaches that allow a better understanding of the molecular mechanisms responsible for autism.

To carry out research on the different causes (genetic, environmental and biological) and consequences of this disease in order to contribute to changing public opinion's view of this handicap and to find possible therapeutic solutions to this disease.

\section{REFERENCES}

[1] Werling, D.M., and Geschwind, D.H. Understanding sex bias in autism spectrumdisorder. Proc. Natl. Acad. Sci. U. S. A.; 2013; 110: 4868-4869.

[2] Lord, C., Risi, S., Lambrecht, L., Cook, E.H., Leventhal, B.L., DiLavore, P.C., Pickles, A., et Rutter, M. The autism diagnostic observation schedule-generic: a standard measure of social and communication deficits associated with the spectrum of autism. J Autism DevDisord 2000; 30:205-223.

[3] Fombonne E. Epidemiology of pervasive developmental disorders. Pediatr Res 2009; 65:591-8.

[4] Tordjman S, Cohen D, Coulon N. Ed. A, Danion-Grillat, C. Bursztejn, Research in autism. In " Child Psychiatry Lavoisier, $2011 ;$ p.210-225

[5] Shelton, J.F.Neurodevelopmental disorders and prenatal residential proximity to agricultural pesticides : the CHARGE study. Environ Health Perspect,. 2014; 122(10):1103-09.

[6] Rivet, T., and Matson, J. Review of gender differences in core symptomatology in autism spectrum disorders. Res. AutismSpectr. Disord, , 2011; 5:957-976.
[7] United Nations Organizations (2008)., Resolution adopted by the General Assembly, 34/139 World Autism Awareness Day,

[8] Myers, S.M., and Johnson, C.P. Management of children with autism spectrum disorders. Pediatrics 2007; 120:1162-1182.

[9] Grafodatskaya D, Chung B, Szatmari P, et al (2010). Autism spectrum disorders andepigenetics. J Am Acad Child Adolesc Psychiatry; 49:794-809.

[10] Durand CM, Betancur C, Boeckers TM, Bockmann J, Chaste P, Fauchereau F, et al. (2007)Mutations in the gene encoding the synaptic scaffolding protein SHANK3 are associated with autism spectrum disorders. Nat Genet;39:25-7.

[11] Ross, J.L., Roeltgen, D.P., Kushner, H., Zinn, A.R., Reiss, A., Bardsley, M.Z., McCauley, E., and Tartaglia, N. (2012). Behavioral and social phenotypes in boys with $47, \mathrm{XYY}$ syndrome or $47, \mathrm{XXY}$ Klinefelter syndrome. Pediatrics129, 769-778.

[12] Roy, M., Dillo, W., Emrich, H.M., and Ohlmeier, M.D. (4009). Asperger's syndrome in adulthood. Dtsch. Ärztebl. Int. 106, 59-64.

[13] Robins, D L, Fein, D., Barton, M. L., \& Green, J. A. (2001). The Modified Checklist for Autism in Toddlers: an initial study investigating the early detection of autism and pervasive developmental disorders. Journal of autism and developmentaldisorders, 31(2), 131- 144.

[14] Sandin S, D Schendal, P Magnusson, et al (2015). Risk of autism associated with the age of the parents and the increasing age difference between the parents. Molecular Psychiatry.

[15] Sato, D., Lionel, A.C., Leblond, C.S., Prasad, A., Pinto, D., Walker, S., O'Connor, I., Russell, C., Drmic, I.E., Hamdan, F.F., et al. (2012). SHANK1 Deletions in Males with Autism Spectrum Disorder. Am. J. Hum. Genet. 90, 879-887. Glasson et al., 2004;

[16] Risi, S., Lord, C., Gotham, K., Corsello, C., Chrysler, C., Szatmari, P., Cook, E.H., Leventhal, B.L., et Pickles, A. (2006). Combining information from multiple sources in the diagnosis of autism spectrum disorders. J Am Acad Child Adolesc Psychiatry 45, 1094 1103.

[17] Volkmar FR, Lord C, Bailey A, et al. (2004). Autism and pervasive developmental disorders. J Child Psychol Psychiatry;45(1):135-70. Turner et al., 2011

[18] Pearson, D.A., Santos, C.W., Aman, M.G., Arnold, L.E., Casat, C.D., Mansour, R., Lane, D.M., Loveland, K.A., Bukstein, O.G., Jerger, S.W., et al. (2013). Effects of extended release methylphenidate treatment on ratings of attentiondeficit/hyperactivity disorder (ADHD) and associated behavior in children with autism spectrum disorders and ADHD symptoms. J. Child Adolesc. Psychopharmacol. 23, 337-351.

[19] American Psychiatric Association. (2003). DSM-IV-TR Diagnostic and Statistical Manual of Mental Disorders, 4th edition, revised text

[20] Courchesne, E. et Pierce, K. (2005). Brain overgrowth in autism during a critical time in development: Implications for frontal pyramidal neuron and interneuron development and connectivity. International Journal of Developmental Neuroscience, 23, 153-170.

[21] Geier, D.A., Kern, J.K., King, P.G., Sykes, L.K., and Geier, M.R. (2012). An evaluation of the role and treatment of elevated male hormones in autism spectrum disorders. Acta Neurobiol. Exp. (Warsz.) 72, 1-17

[22] Jahromi, L.B., Kasari, C.L., M c Cracken, J.T., Lee, L.S.-Y., Aman, M.G., McDougle, C.J., Scahill, L., Tierney, E., Arnold, L.E., Vitiello, B., et al. (2009). Positive effects of methylphenidate on social communication and self-regulation in children with pervasive developmental disorders and hyperactivity. J. Autism Dev. Disord. 39,395-404. 23 Damkjær Maimburg

[24] Kim, S.H., et Lord, C. (2012). New autism diagnostic interviewrevised algorithms for toddlers and young preschoolers from 12 to 47 months of age. J AutismDevDisord42, 82-93.

[25] McLeod Frampton Gwynette, Shawn S. Sidhu, TolgaAtillaCeranoglu, (2018) Electronic Screen Media Use in Youth With Autism Spectrum Disorder. Child AdolescPsychiatric Clin N Am 27 203-219

[26] Idring S, Lundberg M, Sturm H, Dalman C, Gumpert C, Rai D, Lee BK, Magnusson C. (2014).Changes in Prevalence of Autism Spectrum Disorders in 2001-2011: Findings from the Stockholm Youth Cohort. Journal of autism and developmental disorders, epub ahead of print. PMID: 25475364

[27] Volkmar FR, Lord C, Bailey A, et al. (2004). Autism and pervasive developmental disorders. J Child Psychol Psychiatry;45(1):135-70.

[28] Wolstenholme JT, Edwards M, Shetty SR, et al. (2012)Gestational exposure to bisphenol a produces transgenerational changes in behaviors and gene expression. Endocrinology; 153:3828-38 
[29] Volk, H.E., et al. (2013). Traffic-related air pollution, particulate matter, and autism. JAMA Psychiatry,70(1): p. 71-7.

[30] Shattuck, P. T., Grosse, S., Parish, S., \& Bier, D. (2009). Utilization of a Medicaidfunded intervention for children with autism. Psychiatric services (Washington, D.C.), 60(4), 549- 552. doi:10.1176/appi.ps.60.4.549

[31] Wong, L.M., Goodrich-Hunsaker, N.J., McLennan, Y., Tassone, F., Zhang, M., Rivera, S.M., et Simon, T.J. (2014). Eye Movements Reveal Impaired Inhibitory Control in Adult Male Fragile X Premutation Carriers Asymptomatic for FXTAS. Neuropsychology28, 571-584.

[32] Vu, T.H., and Hoffman, A.R. (1997). Imprinting of the Angelman syndrome gene, UBE3A, is restricted to brain. Nature Genetics17, 12-13.
[33] State, M.W., and Levitt, P. (2011). The Conundrums of Understanding Genetic Risks for Autism Spectrum Disorders. Nat. Neurosci. 14, 1499-1506.

[34] Richards, C., Jones, C., Groves, L., Moss, J., et Oliver, C. (2015). Prevalence of autism spectrum disorder phenomenology in genetic disorders: a systematic review and metaanalysis. Lancet Psychiatry2, 909-916

[35] Simonoff, E., Pickles, A., Charman, T., Chandler, S., Loucas, T., Baird, G., (2008). Psychiatric disorders in children with autism spectrum disorders: prevalence, comorbidity, and associated factors in a population-derived sample. J Am Acad Child Adolesc Psychiatry 47, 921-929

[36] Sarachana T, Zhou R, Chen G, et al. (2010). Investigation of posttranscriptional gene regulatory networks associated with autism spectrum disorders by microRNA expression profiling of lymphoblastoid cell lines. Genome Med;2:23 